\title{
Regulation of the somatotropic axis by dietary factors in rainbow trout (Oncorhynchus mykiss)
}

\author{
Pedro Gómez-Requeni ${ }^{1}$, Josep Calduch-Giner ${ }^{1}$, Silvia Vega-Rubín de Celis ${ }^{1}$, Françoise Médale ${ }^{2}$, Sadasivam \\ J. Kaushik ${ }^{2}$ and Jaume Pérez-Sánchez ${ }^{2 *}$ \\ ${ }^{1}$ Instituto de Acuicultura de Torre de la Sal (CSIC), 12595 Ribera de Cabanes, Castellón, Spain \\ ${ }^{2}$ Laboratoire de Nutrition des Poissons, Unité Mixte INRA-IFREMER, 64310 Saint-Pée-sur-Nivelle, France
}

(Received 3 May 2004 - Revised 7 October 2004 - Accepted 11 October 2004)

\begin{abstract}
The activity of the somatotropic axis was analysed in juvenile rainbow trout (Oncorhynchus mykiss) fed either a fishmeal-based diet (FM) or graded levels of plant proteins to replace $50 \%$ (PP50 diet), $75 \%$ (PP75 diet) or $100 \%$ (PP100 diet) of the fishmeal protein. For this purpose, partial cloning and sequencing of the gene encoding rainbow trout growth hormone receptor (GHR) was first accomplished by RT-PCR, using degenerate primers based on the sequences of non-salmonid fish GHR. Growth rates and energy retention were lowered by the PP75 and PP100 diets and a concurrent and progressive increase in plasma levels of growth hormone (GH) was found. However, no changes in hepatic GH binding and total plasma insulin-like growth factor (IGF)-I levels were observed among the four experimental groups. This fact agrees with the lack of changes in hepatic measurements of GHR and IGF-I transcripts. No consistent changes in IGF transcripts were found in peri-visceral adipose tissue and skeletal muscle, but GHR mRNA was up-regulated in the peri-visceral adipose tissue of fish fed the PP75 and PP100 diets, which would favour the lipolytic action of GH. Two specific bands (47 and 33 kDa) of IGF-binding proteins were found in the plasma of all analysed fish, but the sum of the two integrated areas increased progressively with plant protein supply, which might reflect a reduced free IGF availability. Therefore, in our experimental model, the growth impairment could be due, at least in part, to a lowered availability of biologically active IGF (free IGF fraction) rather than to liver GH desensitization or defect in IGF synthesis and release at the systemic and/or paracrineautocrine level.
\end{abstract}

Rainbow trout: Plant proteins: Growth hormone: Growth hormone receptor: Insulin-like growth factor

Growth hormone $(\mathrm{GH})$ plays a central role as a pluripotent endocrine regulator of physiological functions in fish and higher vertebrates (Björnsson, 1997; Pérez-Sánchez, 2000). In mammals, it is now recognized that this pituitary hormone exerts its action by direct interaction with a GH receptor (GHR) on the cell membrane of target tissues, triggering a phosphorylation cascade for signalling and gene expression (Behncken \& Waters, 1999; Zhu et al. 2001). Transmission of the intracellular GHR signal remains unexplored in fish, although this receptor has been cloned and sequenced from several fish species including the goldfish ( $\mathrm{Car}$ assius auratus; Lee et al. 2001), turbot (Scophthalmus maximus; Calduch-Giner et al. 2001), black sea bream (Acanthopagrus schlegeli; Tse et al. 2003), gilthead sea bream (Sparus aurata; CalduchGiner et al. 2003), catfish (Silurus meridionalis; GenBank accession no. AY336104), Japanese flounder (Paralichthys olivaceus; GenBank accession no. AB058418), grass carp (Ctenopharyngodon idella; GenBank accession no. AY283778), masu salmon (Oncorhynchus masou; Fukada et al. 2004) and coho salmon (Oncorhynchus kisutch; GenBank accession no. AF403539 and AF403540). Furthermore, the organization of the GHR gene has been elucidated in turbot and gilthead sea bream (Pérez-Sánchez et al. 2002), and a high conservation of exon-intron boundaries through the evolution of vertebrate species has been reported despite the occurrence of an exclusive fish intron (10/10A) at the C-terminus.

The first observation in fish that shifts in GHR mRNA levels are associated with changes in growth rates has been made in gilthead sea bream, in which the hepatic expression of GHR is up-regulated during the summer growth spurt (Calduch-Giner et al. 2003). In this fish species, we have also found that hepatic GHR are down-regulated by the replacement of fishmeal by plant proteins, which in turn results in decreased growth and expression of hepatic insulin-like growth factor (IGF)-I (Gómez-Requeni et al. 2004). Currently, there are no data in rainbow trout (Oncorhynchus mykiss) about the effect of dietary $\mathrm{N}$ source on the activity and regulation of the somatotropic axis. To address this issue, in the present work trout $G H R$ was partially cloned and sequenced in order to establish the tissue-specific regulation of GHR transcripts in fish fed diets containing fishmeal or plant proteins. Further, hepatic GH binding, tissue-specific expression of IGF, and plasma levels of GH, IGF-I and IGF carriers (IGF-binding proteins, IGFBP) were analysed. 


\section{Materials and methods}

\section{Experimental diets and feeding trial}

As shown in Table 1, four diets were formulated to contain either fishmeal as the sole protein source (FM diet) or graded levels of plant proteins to replace $50 \%$ (PP50 diet), $75 \%$ (PP75 diet) or $100 \%$ (PP100 diet) of the fishmeal protein. Crystalline amino acids were added to plant protein-based diets to meet the indispensable amino acid profile. Fish oil was added to maintain the dietary crude fat content constant in all diets. To measure digestibility, $1 \%$ chromic oxide was added as an inert marker and it was determined after perchloric acid digestion (Bolin et al. 1952). Faeces were collected twice daily using a faecal collection apparatus (Choubert et al. 1982), and apparent digestibility coefficients were calculated as described elsewhere (Maynard \& Loosli, 1969).

The feeding trial was performed in the experimental fish farm of INRA (Donzacq, Landes, France) under natural photoperiod. Rainbow trout of $19 \mathrm{~g}$ initial body weight were reared in sixteen circular 1000-litre glass-fibre tanks in groups of seventy-five fish each. Water was supplied from natural springs and its temperature ranged from 16 to $18^{\circ} \mathrm{C}$ over the course of the trial (21 March to 7 June).

Each experimental diet was randomly distributed by hand to quadruplicate groups of fish for 11 weeks. Feed was offered twice daily near to visual satiety and feed consumption was

Table 1. Ingredients, chemical composition and apparent digestibility coefficients (ADC) of the four experimental diets

\begin{tabular}{|c|c|c|c|c|}
\hline & FM & PP50 & PP75 & PP100 \\
\hline \multicolumn{5}{|l|}{ Ingredient $(\mathrm{g} / \mathrm{kg})$} \\
\hline Fishmeal & 637.9 & $319 \cdot 0$ & 159.5 & 0 \\
\hline Corn gluten meal & 0 & $116 \cdot 0$ & $177 \cdot 1$ & $232 \cdot 4$ \\
\hline Wheat gluten & 0 & 100 & 150 & 200 \\
\hline Extruded peas (Aquatex) & 0 & $80 \cdot 0$ & $120 \cdot 0$ & $163 \cdot 3$ \\
\hline Rapeseed meal (Primor 00) & 0 & $46 \cdot 9$ & $75 \cdot 0$ & $100 \cdot 0$ \\
\hline Extruded whole wheat & $203 \cdot 4$ & $110 \cdot 2$ & $42 \cdot 5$ & 0 \\
\hline Fish oil & $128 \cdot 6$ & $143 \cdot 6$ & $151 \cdot 1$ & $158 \cdot 7$ \\
\hline Binder ( $\mathrm{Na}$ alginate) & 10 & 10 & 10 & 10 \\
\hline Mineral premix* & 10 & 10 & 10 & 10 \\
\hline Vitamin premix ${ }^{*}$ & 10 & 10 & 10 & 10 \\
\hline $\mathrm{CaHPO}_{4} \cdot 2 \mathrm{H}_{2} \mathrm{O}(18 \% \mathrm{P})$ & 0 & $16 \cdot 1$ & $37 \cdot 8$ & 40 \\
\hline L-Arg & 0 & $6 \cdot 2$ & 9.5 & $12 \cdot 5$ \\
\hline L-His & 0 & 1.9 & 2.9 & 3.9 \\
\hline L-Lys & 0 & $13 \cdot 8$ & $20 \cdot 8$ & $27 \cdot 6$ \\
\hline DI-Met & 0 & $2 \cdot 0$ & $3 \cdot 1$ & $4 \cdot 1$ \\
\hline L-Trp & 0 & $1 \cdot 3$ & $2 \cdot 1$ & $2 \cdot 7$ \\
\hline L-Thr & 0 & $4 \cdot 1$ & $6 \cdot 2$ & $8 \cdot 3$ \\
\hline L-lle & 0 & 3.5 & $5 \cdot 3$ & $7 \cdot 1$ \\
\hline L-Val & 0 & 4.7 & $7 \cdot 0$ & $9 \cdot 4$ \\
\hline \multicolumn{5}{|l|}{ Analytical composition } \\
\hline DM (\%) & $94 \cdot 4$ & $92 \cdot 2$ & 91.5 & 91.6 \\
\hline Crude protein (\% DM) & $51 \cdot 5$ & $50 \cdot 3$ & $49 \cdot 1$ & $48 \cdot 6$ \\
\hline Crude fat (\% DM) & $19 \cdot 7$ & $19 \cdot 6$ & $19 \cdot 6$ & $19 \cdot 2$ \\
\hline Gross energy (kJ/g DM) & $22 \cdot 7$ & 23.5 & 23.9 & 23.6 \\
\hline IAA (\% DM) & $22 \cdot 2$ & $22 \cdot 9$ & $22 \cdot 1$ & 23.9 \\
\hline DAA (\% DM) & $21 \cdot 8$ & $23 \cdot 3$ & $22 \cdot 1$ & $23 \cdot 7$ \\
\hline IAA:DAA & $1 \cdot 0$ & 0.9 & $1 \cdot 0$ & $1 \cdot 0$ \\
\hline \multicolumn{5}{|l|}{ ADC values (\%) } \\
\hline $\mathrm{DM}$ & 83.4 & $79 \cdot 2$ & $76 \cdot 8$ & $72 \cdot 0$ \\
\hline Crude protein & 93.4 & 93.7 & 93.9 & 93.6 \\
\hline Crude fat & $95 \cdot 6$ & $92 \cdot 8$ & 91.6 & $90 \cdot 3$ \\
\hline Starch & 99.2 & 80.7 & 75.5 & $56 \cdot 2$ \\
\hline Energy & $92 \cdot 0$ & $87 \cdot 8$ & $86 \cdot 4$ & $82 \cdot 7$ \\
\hline
\end{tabular}

IAA, indispensable amino acids; DAA, dispensable amino acids.

*As per National Research Council (1993). recorded daily. Every 3 weeks fish were counted and groupweighed.

Whole-body composition for the calculation of retention efficiencies was determined in an initial pooled sample of fifteen fish and in pools of six fish per tank (twenty-four fish per diet) at the end of the growth trial. Specimens for body analysis were ground, and small aliquots were dried $\left(110^{\circ} \mathrm{C}\right)$ to estimate water content. The remaining samples were freeze-dried and chemical analyses for protein, fat and ash were made following published methods (Association of Official Analytical Chemists, 1990).

\section{Blood and tissue sampling}

At the end of the growth trial and following overnight fasting, blood samples were taken from caudal vessels with heparinized syringes (twenty animals per diet). Plasma was drawn after centrifugation at $3000 \mathrm{~g}$ for $20 \mathrm{~min}$ at $4^{\circ} \mathrm{C}$ and stored at $-30^{\circ} \mathrm{C}$ until hormone analysis. Liver, white muscle and peri-visceral adipose tissue of twelve animals per diet were rapidly excised, frozen in liquid $\mathrm{N}_{2}$, and stored at $-80^{\circ} \mathrm{C}$ until use for GH-binding and real-time PCR assays.

\section{Plasma hormone assays}

Plasma GH levels were determined by a double antibody RIA using recombinant trout $\mathrm{GH}$ (Eurogentec, Liège, Belgium) as tracer and standard. Anti-salmon GH serum (GroPep, Adelaide, Australia) was used as a first antibody (1:25000). A goat antirabbit IgG (1:20) (Biogenesis, Poole, UK) was used as precipitating antibody, and the sensitivity and mid range of the assay were 0.05 and $0.6 \mu \mathrm{g} / \mathrm{l}$, respectively.

After acid-ethanol precipitation to avoid IGFBP interference, total plasma levels of IGF-I were measured by a homologous RIA based on the use of recombinant trout IGF-I (GroPep) as tracer and standard, and anti-trout IGF-I serum (GroPep; 1:16000) as a first antibody. A goat anti-rabbit IgG (1:20; Biogenesis) was used as a precipitating antibody. The sensitivity and mid range of the assay were 0.05 and $0.8 \mu \mathrm{g} / \mathrm{l}$, respectively.

\section{Insulin-like growth factor-binding protein activity}

Plasma samples were diluted 1:4 in sample buffer (10\% glycerol, $12.5 \%$ Tris-OH, $2 \%$ SDS and $0.05 \%$ bromophenol blue), heated at $60^{\circ} \mathrm{C}$ for $15 \mathrm{~min}$ and immediately put in ice for $1 \mathrm{~min}$. Then, $15 \mu \mathrm{l}$ samples were electrophoresed under non-reducing conditions in a $12 \%$ separating polyacrylamide gel (SDS-PAGE) for $1 \mathrm{~h}$ at 200 W using a Mini-Protean II (Bio-Rad, Hercules, CA, USA). Gels were placed in transfer buffer ( $25 \mathrm{~mm}$-Tris-OH, $192 \mathrm{~mm}$-glycine, $20 \% \mathrm{CH}_{3} \mathrm{OH}$; $\left.\mathrm{pH} 8.1-8.5\right)$ for $15 \mathrm{~min}$ and electroblotted to Immun-Blot PVDF membranes (Bio-Rad) at $100 \mathrm{~W}$ for $90 \mathrm{~min}$ at room temperature. Membranes were then placed in a blocking solution $(5 \%$ dry non-fat milk in Tris-buffered saline (TBS): 20 mm-Tris- $\mathrm{OH}, 500 \mathrm{~mm}-\mathrm{NaCl}, 0.05 \% \mathrm{NaN}_{3} ; \mathrm{pH} 7.5$ ) for $1 \mathrm{~h}$ at room temperature, and washed for $10 \mathrm{~min}$ with $0.1 \%$ Tween-20 in TBS. After this, membranes were incubated for $15 \mathrm{~h}$ at $4^{\circ} \mathrm{C}$ in the probe buffer ( $1 \%$ bovine serum albumin, $0.1 \%$ Tween-20 in TBS) containing $\left[{ }^{125} \mathrm{I}\right]$-labelled recombinant trout IGF-I $(200000 \mathrm{cpm} / \mathrm{ml})$. The binding specificity was established by adding an excess of human IGF-I $(2 \mu \mathrm{g} / \mathrm{ml})$. Membranes were exposed for 6 days at $-80^{\circ} \mathrm{C}$ to Biomax MS films (Kodak, Rochester, NY, USA). Autoradiographs were scanned with a GS-710 Cali- 
brated Imaging Densitometer (Bio-Rad), and bands quantified using Quantity-One 4.2.3 software (Bio-Rad).

\section{Growth hormone binding}

Hepatic GH binding was assayed by a radioreceptor assay (Yao et al. 1991), based on the use of recombinant trout GH (Eurogentec) as iodinated tracer and cold hormone to measure total and non-specific GH binding.

\section{Partial cloning and sequencing of trout growth hormone receptor}

Total liver RNA was extracted by the acid guanidium thiocyanate-phenol-chloroform method (Chomczynski \& Sacchi, 1987). The purified RNA was treated with DNase I, and $2 \mu \mathrm{g}$ were reverse-transcribed with 200 U Superscript II (Life Technologies, Gaithesburg, MD, USA) using oligo(dT) 17 as anchor primer. Degenerate forward (GHR1: 5'-GGA GAC NTT YCG NTG YTG GTG GA) and reverse (GHR2: 5'-TGT CGG ACA CCT GGG CRT ARA ART C) primers for GHR cloning and sequencing were designed on the basis of their previous success in turbot and gilthead sea bream (Calduch-Giner et al. 2001, 2003). For PCR, $2 \mu \mathrm{l}$ RT reaction were amplified with $0 \cdot 2 \mathrm{~mm}$ each dNTP, $1 \mu \mathrm{M}$ forward and reverse primers and $2.5 \mathrm{U}$ Platinum Taq DNA Polymerase (Life Technologies) in a final volume of $50 \mu \mathrm{l}$ of reaction buffer. After 35 cycles $\left(94^{\circ} \mathrm{C}\right.$ for $1 \mathrm{~min}, 54^{\circ} \mathrm{C}$ for $2 \mathrm{~min}, 72^{\circ} \mathrm{C}$ for $3 \mathrm{~min}$ ), amplified fragments were run in agarose gels, and bands of interest were purified (Wizard PCR Preps; Promega, Madison, WI, USA) and sequenced by the dideoxy chain termination method (ABI PRISM dRhodamine terminator cycle sequencing kit; Perkin-Elmer, Wellesley, MA, USA). The resulting sequence has been submitted to the GenBank database under accession no. AF438178.

\section{Structure and phylogenetic analysis of growth hormone receptors}

Putative transmembrane regions were predicted with HMMTOP version 2.0 (http://www.enzim.hu/hmmtop; Tusnády \& Simon, 2001). Potential N-linked glycosylation sites were determined with Gene Runner version 3.02 software (Hastings Software, Hastings, NY, USA). Protein sequence alignments were made by means of ClustalX software (Thompson et al. 1994). Phylogenetic comparison of protein sequences was carried out with MEGA2 version 2.1 software (Kumar et al. 2001).

\section{Northern Blot}

A cDNA probe comprising $552 \mathrm{nt}$ of the extracellular domain of trout GHR was PCR-amplified with $5^{\prime}$-GAA TTC ACG GAA CCC GGA GCA CTG and 5'-GAA TTC CGT TGA CTC TTT ATT GGG A as forward and reverse primers, respectively. Amplified PCR fragments were ligated into pGEM-T vector according to the manufacturer's instructions (Promega) and used to transform competent Escherichia coli (JM109 strain). Recombinant plasmids were purified (SV Minipreps; Promega), and the probe was excised with appropriate restriction enzymes, gel-purified and labelled with $0.74 \mathrm{Mbq}\left[{ }^{32} \mathrm{P}\right] \mathrm{dCTP}$ by decanucleotide random priming (Decalabel DNA Labeling Kit; Fermentas, Hanover, MD, USA). Liver total RNA (30 $\mu \mathrm{g})$ from fish fed FM and PP100 diets was separated in a $1 \%$ denaturing agarose/ formaldehyde gel, transferred into positively charged nylon membranes by vacuum transfer (Bio-Rad) in standard saline citrate $(10 \times)$, and UV cross-linked. Prehybridization $(3 \mathrm{~h})$ and hybridization (overnight) were performed at $65^{\circ} \mathrm{C}$ in $0.5 \mathrm{~mm}$ $\mathrm{Na}_{2} \mathrm{HPO}_{4}$ (pH 7.2), 1 mM-EDTA, $7 \%$ SDS and $1 \%$ bovine serum albumin. After washing at room temperature, dried membranes were exposed to Biomax MS films (Kodak) with intensifying screens for 7 days at $-80^{\circ} \mathrm{C}$.

\section{Real-time PCR assays}

Tissue expression of $G H R$ and $I G F$ genes was assessed in liver, skeletal muscle and adipose tissue by means of SYBR Green I real-time PCR assays as described elsewhere in gilthead sea bream (Calduch-Giner et al. 2003). $\beta$-Actin was chosen as a housekeeping gene, and specific primers for each gene of interest were designed with the Primer Express software of Applied Biosystems (Foster City, CA, USA). Primers for GHR (forward: 5'CGA TAC CTT GTG CTT CGA ATT G; reverse: 5'-TGA TGT TCA GCA GCG TCC AA) amplified a $80 \mathrm{bp}$ amplicon between 203 and 282 nt positions of trout GHR. IGF-I primers (forward: 5'-GCG ATG TGC TGT GTC TCC TG; reverse: 5'AGC CTC TCT CTC CAC ACA CAA AC) amplified a 148 bp amplicon between the signal peptide and the B domain, with no alternative splicing in this region (Chen et al. 1994). Primers for trout $I G F-I I$ (forward: $5^{\prime}$-TAC CAC TCA GTT TGT CAC ACC T; reverse: 5'-CCG AAG CCA CTT CAA CAA TGT A) amplified a $130 \mathrm{bp}$ amplicon between the signal peptide and the B domain. Primers for $\beta$-actin (forward: $5^{\prime}$-GAT GGG CCA GAA AGA CAG CTA; reverse: 5'-TCG TCC CAG TTG GTG ACG AT) amplified a 105 bp amplicon.

Total RNA $(1 \mu \mathrm{g})$ from tissues was extracted, treated with DNase I and reverse-transcribed with oligo-dT as described earlier (cloning and sequencing). PCR amplification and analysis was performed on an ABI PRISM 5700 Sequence Detection System (Applied Biosystems). The final volume of PCR reactions was $25 \mu$, using SYBR Green PCR Master Mix (Applied Biosystems) and specific primers $(0 \cdot 9 \mu \mathrm{M})$. The real-time PCR protocol was $10 \mathrm{~min}$ at $95^{\circ} \mathrm{C}$ followed by 40 cycles of $15 \mathrm{~s}$ at $95^{\circ} \mathrm{C}$ and $1 \mathrm{~min}$ at $60^{\circ} \mathrm{C}$. Standard curves were generated by amplifying serial dilutions of known quantities of recombinant plasmids for each gene of interest. The dynamic range of standard curves spanned at least five orders of magnitude, and the amount of product in a particular sample was determined by interpolation of the cycle threshold value $(\mathrm{Ct})$. For each particular gene, the efficiency of the PCR reaction (91-98\%) was the same for serial dilutions of standards and RT reactions. Specificity of amplified PCR products was determined by DNA sequencing and analysis of melting curves on real-time PCR assays. Data were normalized by the delta-delta method (Livak \& Schmittgen, 2001), after the verification that $\mathrm{Ct}$ values for $\beta$-actin amplification did not change significantly among tissues and experimental conditions $(\mathrm{Ct}=19 \cdot 9-20 \cdot 3)$.

\section{Statistical analysis}

Data were analysed by one-way ANOVA, followed by the Student-Newman-Keuls test at a significance level of $P<0.05$. Tank average values were used as experimental units for statistical analysis of growth performance.

\section{Results}

Molecular characterization of trout growth hormone receptor

The partial nucleotide sequence of trout $G H R$ was determined by RT-PCR, using degenerated primers based on available sequences 
of GHR of non-salmonid fish. PCR amplification yielded a single cDNA fragment with six potential N-linked glycosylation sites, four of which are conserved in all the available sequences of non-salmonid GHR (Fig. 1(A)). A strict conservation of extracellular cysteine residues, the characteristic GHR ligand-binding motif (Y/F)GEFS, box 1 and box 2 cytoplasmatic domains and intracellular tyrosine residues were also found (Fig. 1(B)).
Northern blot of liver RNA with a specific cDNA probe for the trout GHR outlined the expression of a single transcript around $8 \mathrm{~kb}$ (Fig. 2). The overall identity of the deduced amino acid sequence of trout GHR remained high compared with GHR of non-salmonid fish (turbot: $58 \%$; black sea bream: $57 \%$; gilthead sea bream and Japanese flounder: $56 \%$; grass carp and goldfish: $55 \%$; catfish: $47 \%$ ), but decreased by up to $45 \%$ when comparisons

(A)
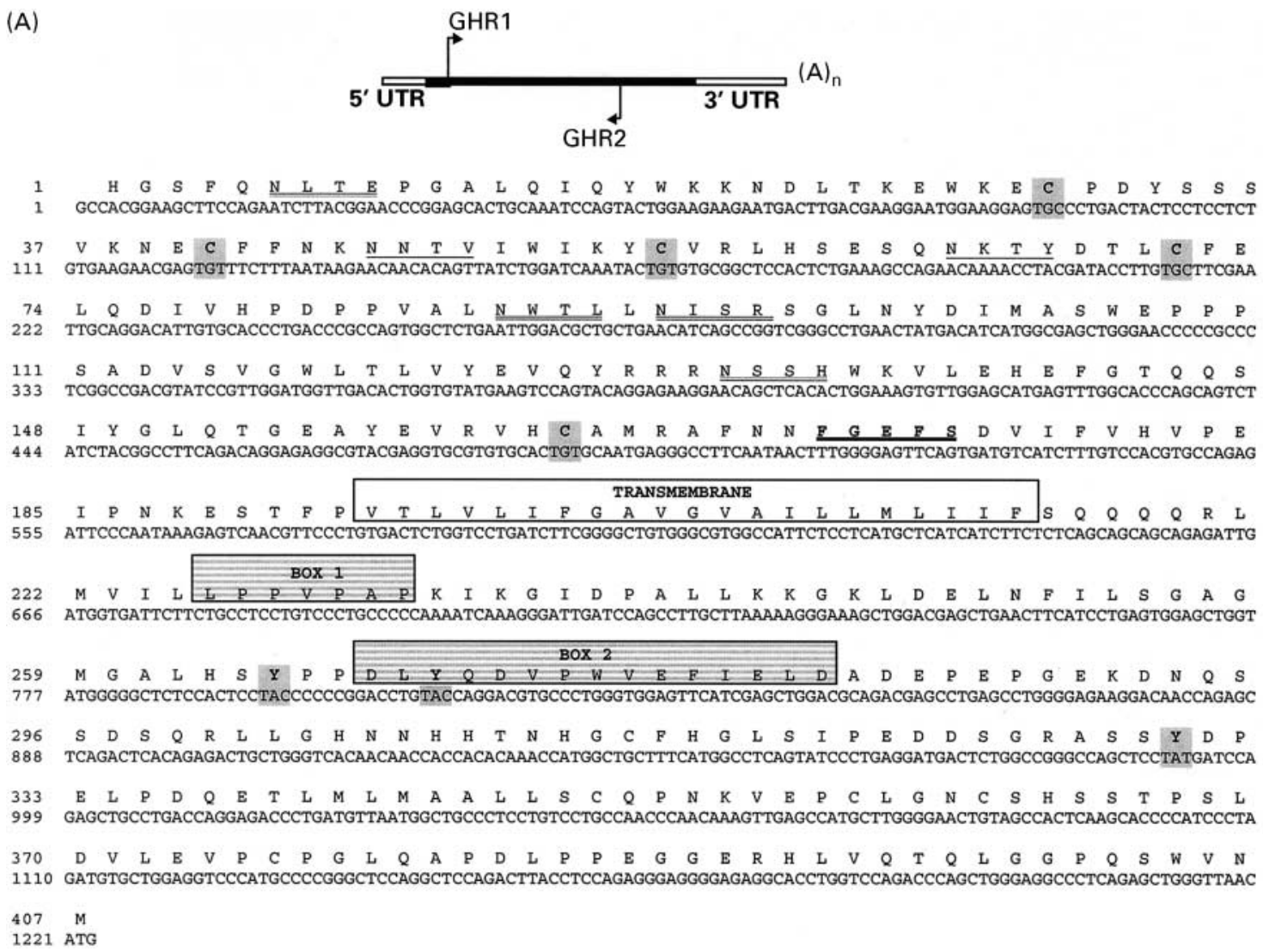

(B)

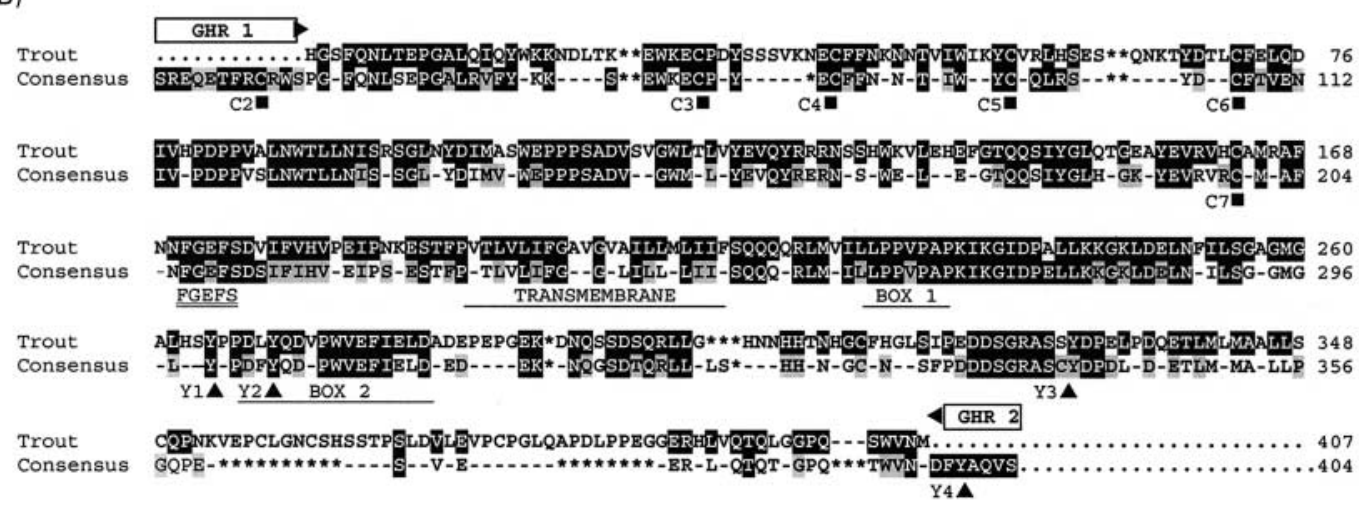

Fig. 1. (A) Schematic representation of PCR strategy for cloning and sequencing of the trout growth hormone receptor (GHR) using degenerate forward and reverse primers (GHR1 and GHR2, respectively; UTR, untranslated region. Potential N-linked glycosylation sites are single or double underlined. Double underline indicates glycosylation sites strictly conserved in all the available GHR of non-salmonid fish. FGFES motif is in bold and underlined. Extracellular cysteines and cytoplasmic tyrosines are in bold and boxed in grey. Transmembrane, box 1 and box 2 domains are boxed. (B) Amino acid alignment of rainbow trout GHR and consensus sequence of non-salmonid GHR (catfish (AY336104), goldfish (AF293417), grass carp (AY283778), gilthead sea bream (AF438176), black sea bream (AF502071), turbot (AF352396), Japanese flounder (AB058418) and masu salmon (AB071216)). Identical and homologous amino acids are in black in trout and consensus sequences. Hyphens in the consensus sequence indicate a lack of conservation. Letters with a white background in the consensus sequence indicate amino acid conservation higher than $50 \%$, grey background indicates conservation higher than $65 \%$, and black background indicates conservation from $85 \%$ to $100 \%$. Asterisks indicate positions where gaps are introduced for a better alignment. Transmembrane domain, FGEFS motif, box 1 and box 2 domains are indicated. Extracellular cysteine and intracellular tyrosine residues are labelled by squares and triangles. 


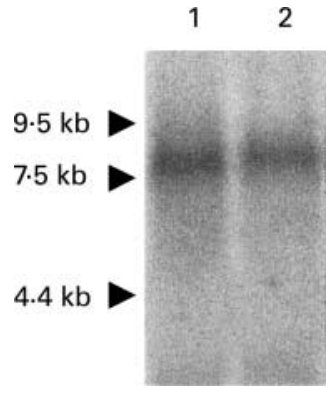

Fig. 2. Northern blot analysis of total liver RNA with an extracellular cDNA probe encoding for the trout growth hormone receptor: lane 1, fish fed diet FM; lane 2, fish fed diet PP100 (for details of the experimental diets, see Table 1, p. 354). Migration of RNA size markers is indicated.

were made with coho and masu salmon GHR. Thus, in the phylogenetic analysis, trout GHR and GHR of non-salmonid fish were put in the same node according to the present hierarchy of fish. A second node was found for the available sequences of coho salmon and masu salmon, although all fish GHR were put in the same cluster when GHR of tetrapods were included as an outgroup (Fig. 3).

Growth performance and nutritional regulation of the somatotropic axis

Juvenile rainbow trout grew from $19 \mathrm{~g}$ to $111-147 \mathrm{~g}$ over the course of trial. Feed intake in fish fed PP75 and PP100 diets was significantly higher than in the other two experimental groups. However, final body weight, specific growth rates, feed efficiency, $\mathrm{N}$ retention and energy retention were progressively and significantly reduced with the 75 and $100 \%$ replacement diets (Table 2).

Plasma levels of $\mathrm{GH}$ increased progressively with poorer growth, and significant differences between FM and PP100 groups were found at the end of the trial in overnight fasted fish (Fig. 4(A)). No significant changes in hepatic GH binding and total plasma IGF-I levels were found among groups (Fig. 4(B) and (C)).

As shown in Table 3, measurements of GHR and IGF transcripts of the liver tissue of the two extreme groups (FM and PP100 fish) did not reveal any significant effect of dietary treatment. In muscle and peri-visceral adipose tissue, no consistent changes in IGF-I and IGF-II expression were found among all the experimental groups. However, in the peri-visceral adipose tissue, GHR transcripts were up-regulated by the 75 and $100 \%$ replacement diets. The same was found in the muscle of fish fed diet PP100, although this increase was not statistically significant.

Western ligand blotting showed the existence of two specific IGFBP bands ( 47 and $33 \mathrm{kDa}$ ) regardless of dietary treatment. The sum of the integrated area for these two bands increased with poorer growth, and this increase was parallel to the increase of the ratio 47:33 $\mathrm{kDa}$ IGFBP (Fig. 5).

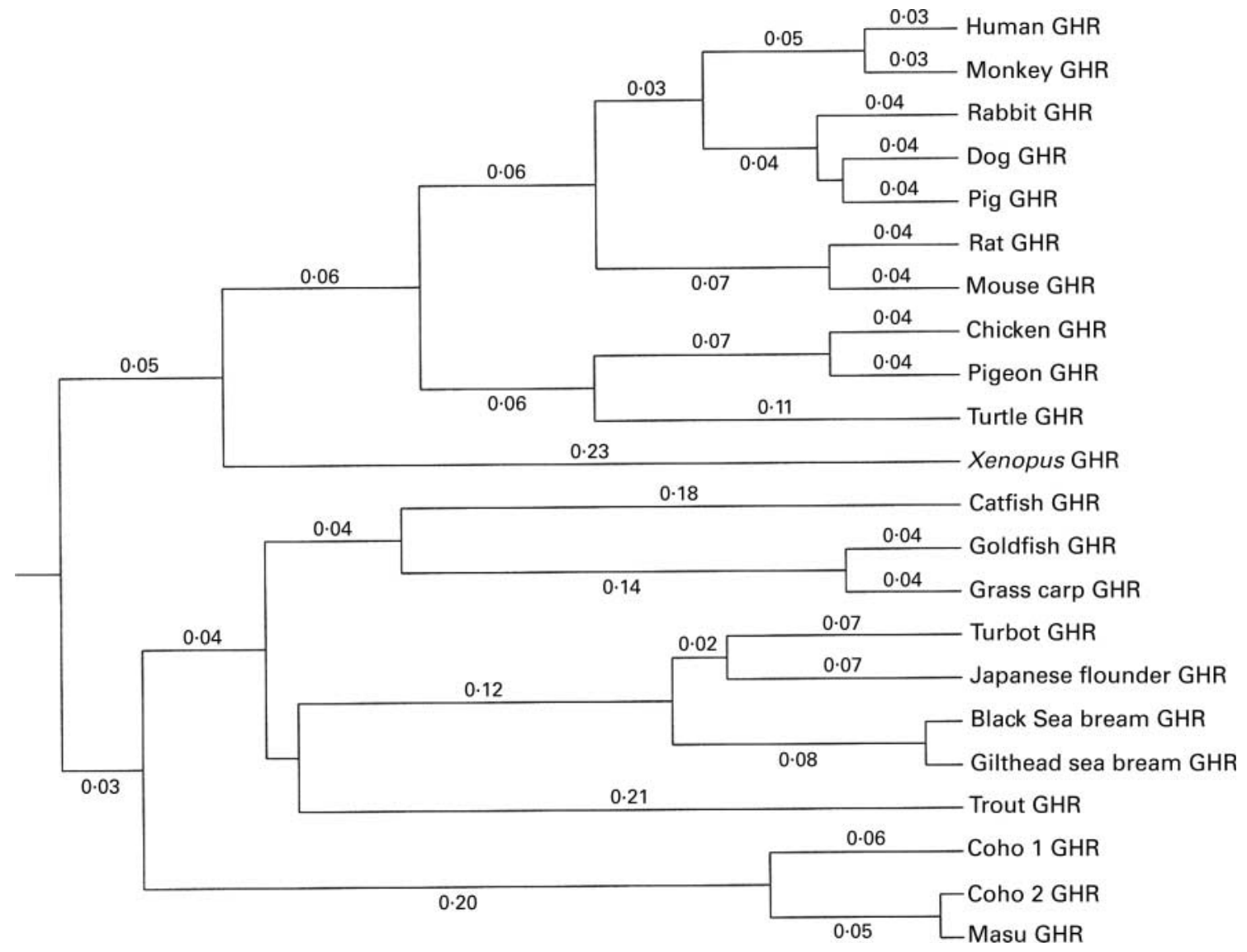

Fig. 3. Phylogenetic tree of growth hormone receptors (GHR) made with MEGA2 version 2.1 software (Kumar et al. 2001). GenBank accession no.: man, NM_000163; monkey, U84589; dog, AF133835; pig, X54429; rabbit, AF015252; mouse, NM_010284; rat, NM_017094; turtle, AF211173; chicken, M74057; pigeon, D84308; Xenopus, AF193799; turbot, AF352396; Japanese flounder, AB058418; black sea bream, AF502071; gilthead sea bream, AF438176; rainbow trout, AF438178; catfish, AY336104; goldfish, AF293417; grass carp, AY283778; coho 1, AF403539; coho 2, AF403540; masu, AB071216. 
Table 2. Data on growth performance and nutrient retention of fish fed the four experimental diets*

(Mean values with their standard error of four groups)

\begin{tabular}{|c|c|c|c|c|c|c|c|c|}
\hline & \multicolumn{2}{|c|}{ FM } & \multicolumn{2}{|c|}{ PP50 } & \multicolumn{2}{|c|}{ PP75 } & \multicolumn{2}{|c|}{ PP100 } \\
\hline & Mean & $\mathrm{SE}$ & Mean & SE & Mean & SE & Mean & SE \\
\hline Initial body weight (g) & $19 \cdot 2$ & 0.1 & $19 \cdot 2$ & 0.1 & $19 \cdot 2$ & 0.1 & $19 \cdot 2$ & 0.05 \\
\hline Final body weight $(\mathrm{g})$ & $147 \cdot 1^{c}$ & 0.9 & $142 \cdot 4^{\mathrm{C}}$ & 1.3 & $135 \cdot 6^{\mathrm{b}}$ & $2 \cdot 4$ & $111 \cdot 1^{\mathrm{a}}$ & $1 \cdot 2$ \\
\hline Feed intake (g DM/kg ABW per d) & $14 \cdot 9^{\mathrm{a}}$ & 0.1 & $14 \cdot 8^{\mathrm{a}}$ & 0.1 & $15 \cdot 4^{\mathrm{b}}$ & 0.1 & $15 \cdot 4^{\mathrm{b}}$ & 0.05 \\
\hline SGR† (\%) & $2 \cdot 61^{\mathrm{c}}$ & 0.01 & $2 \cdot 57^{\mathrm{c}}$ & 0.005 & $2 \cdot 51^{\mathrm{b}}$ & 0.02 & $2 \cdot 25^{\mathrm{a}}$ & 0.01 \\
\hline FE‡ & $1.33^{c}$ & 0.01 & $1 \cdot 29^{c}$ & 0.01 & $1 \cdot 25^{\mathrm{b}}$ & 0.005 & $1 \cdot 17^{\mathrm{a}}$ & 0.005 \\
\hline PERß & $2 \cdot 58^{\mathrm{C}}$ & 0.02 & $2 \cdot 63^{\mathrm{C}}$ & 0.02 & $2.55^{\mathrm{b}}$ & 0.01 & $2 \cdot 42^{\mathrm{a}}$ & 0.005 \\
\hline \multicolumn{9}{|l|}{ Retention (\% digestible intake) } \\
\hline $\mathrm{N}$ & $48 \cdot 2^{\mathrm{c}}$ & 0.6 & $46 \cdot 9^{c}$ & 0.2 & $44 \cdot 3^{b}$ & 0.5 & $40 \cdot 3^{a}$ & 0.9 \\
\hline Lipid & 93.9 & $2 \cdot 0$ & 94.9 & $2 \cdot 8$ & $94 \cdot 2$ & 0.3 & $90 \cdot 9$ & 1.8 \\
\hline Energy & $61 \cdot 0^{\mathrm{b}}$ & $1 \cdot 1$ & $59 \cdot 9^{b}$ & 0.7 & $57 \cdot 1^{\mathrm{a}}$ & 0.3 & $56 \cdot 6^{a}$ & 0.1 \\
\hline
\end{tabular}

ABW, average body weight; SGR, specific growth rate; FE, feed efficiency; PER, protein efficiency ratio.

${ }^{\mathrm{a}, \mathrm{b}, \mathrm{c}}$ Mean values within a row with unlike superscript letters were significantly different among dietary treatments (Student-Newman-Keuls test; $P<0.05$ ). * For details of the experimental diets, see Table 1 (p. 354).

†SGR $=[100 \times($ In final fish weight $($ In initial fish weight) $)]$ days.

$\ddagger \mathrm{FE}=$ wet weight gain/dry feed intake.

$\S \mathrm{PER}=$ wet weight gain/protein intake

\section{Discussion}

Knowledge on the mode of action and regulation of the GH-IGF axis in fish is increasing considerably. One major advance is the cloning and sequencing of GHR in salmonid and non-salmonid fish. However, it is noticeable that available sequences of coho salmon and masu salmon lack one pair of extracellular cysteine residues (C5, C6) and three intracellular tyrosine ones (Y1, Y3, Y6), which are already conserved in the GHR of tetrapods and non-salmonid fish (Zhu et al. 2001; Pérez-Sánchez et al. 2002). Several authors have speculated about a divergent evolution of GHR in salmonids (Björnsson et al. 2002). Nevertheless, the trout sequence reported herein retains all cysteine and tyrosine residues, and in consequence this salmonid cytokine receptor is related in phylogenetic trees to GHR of non-salmonid fish rather than to previously reported GHR of salmonid fish. The tissue expression of trout GHR has been confirmed by Northern blot, and interestingly the molecular weight of the detected band was two-fold higher than that found for gilthead sea bream GHR mRNA (Calduch-Giner et al. 2003), which suggests the presence of long untranslated regions in trout GHR. In this scenario, it must be noted that ongoing studies support the duplication of GHR in the genome of most fish species, including salmonid and non-salmonid fish (Saera-Vila et al. 2005). In the present study we have analysed the same GHR as that first described in non-salmonid fish, which acts as a functional and specific GHR in transfection assays (Lee et al. 2001; Tse et al. 2003), and is perhaps the retained $G H R$ gene in all vertebrate species.

Plasma GH levels are increased by fasting and nutritional changes arising from decreased dietary protein:energy in a wide variety of fish species, including salmonids (Varnavsky et al. 1995; Johnsson et al. 1996; Pottinger et al. 2003), striped bass (Morone saxatilis; Small et al. 2002), tilapia (Oreochromis mossambicus; Weber \& Grau, 1999) and gilthead sea bream (PérezSánchez et al. 1995; Company et al. 2001). Recent gilthead sea bream studies also indicate that plasma GH levels are up-regulated in fish fed diets with reduced nutritive value as a result of

Table 3. Data on liver, muscle and adipose tissue expression of growth hormone receptor (GHR), insulin-like growth factor (IGF)-I and IGF-II (real-time PCR assays) in fish fed the four experimental diets*

(Mean values with their standard error of five to seven fish per groups)

\begin{tabular}{|c|c|c|c|c|c|c|c|c|}
\hline & \multicolumn{2}{|c|}{ FM } & \multicolumn{2}{|c|}{ PP50 } & \multicolumn{2}{|c|}{ PP75 } & \multicolumn{2}{|c|}{ PP100 } \\
\hline & Mean & SE & Mean & SE & Mean & SE & Mean & SE \\
\hline \multicolumn{9}{|l|}{ Liver } \\
\hline GHR & 0.90 & 0.06 & & & & & 1.00 & 0.12 \\
\hline IGF-I & 0.84 & 0.02 & & & & & 1.00 & 0.06 \\
\hline IGF-II & 0.99 & 0.16 & & & & & 1.00 & 0.04 \\
\hline \multicolumn{9}{|c|}{ White muscle } \\
\hline GHR & 0.77 & 0.11 & 0.81 & 0.17 & 0.77 & 0.13 & 1.00 & 0.18 \\
\hline IGF-I & 0.86 & 0.11 & 0.87 & 0.10 & 0.89 & 0.14 & 0.90 & 0.09 \\
\hline IGF-II & 0.96 & 0.15 & 1.00 & 0.17 & 0.61 & 0.06 & 0.72 & 0.07 \\
\hline \multicolumn{9}{|c|}{ Adipose tissue } \\
\hline GHR & $0.56^{a}$ & 0.11 & $0.58^{\mathrm{ab}}$ & 0.09 & $0 \cdot 70^{\mathrm{b}}$ & $0 \cdot 10$ & $1 \cdot 00^{b}$ & 0.11 \\
\hline IGF-I & 0.70 & 0.13 & 0.94 & 0.05 & 0.98 & 0.25 & 1.03 & 0.18 \\
\hline IGF-II & 0.96 & 0.08 & 0.93 & 0.03 & 0.94 & 0.05 & 1.00 & 0.20 \\
\hline
\end{tabular}

Values presented are in arbitrary units.

${ }_{a, b}$ Mean values within a row with unlike superscript letters were significantly different among dietary treatments (Student-Newman-Keuls test; $P<0.05$ ).

${ }^{*}$ For details of the experimental diets, see Table 1 (p. 354). 

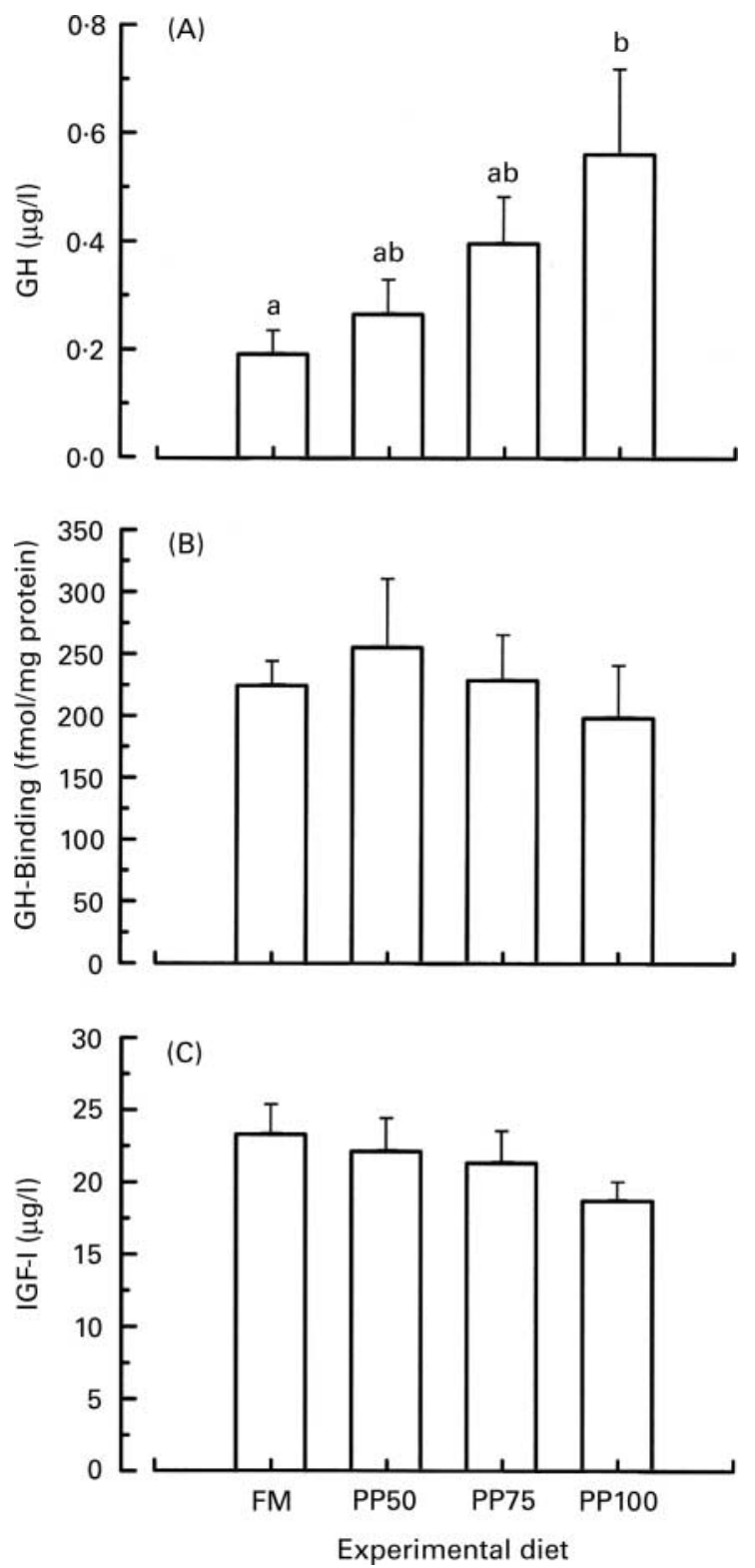

Fig. 4. (A) Plasma levels of growth hormone (GH), (B) hepatic $\mathrm{GH}$ binding and $(C)$ plasma levels of insulin-like growth factor (IGF)-I in fish fed the four experimental diets. For details of the experimental diets, see Table 1 (p. 354). Values are means with their standard errors shown by vertical bars for ten to fifteen animals. ${ }^{a, b}$ Mean values with unlike superscript letters were significantly different $(P<0.05)$.

changes in dietary amino acid profile (Gómez-Requeni et al. 2003) and protein source (Gómez-Requeni et al. 2004). In this context, the GH rise is probably due to a reduced negative feedback inhibition of hepatic IGF-I. This is consistent with a decreased hepatic expression of GHR and IGF-I genes, which in turn results in a lowered plasma IGF-I concentration in conjunction with a reduction of feed intake and weight gain in juvenile gilthead sea bream fed with full plant protein diets (GómezRequeni et al. 2004). In trout, the same kind of experimental diets induced herein a progressive decrease of weight gain with the $75 \%$ and $100 \%$ replacement of fishmeal, but this condition was related to the increase of feed intake, which suggests some state of enhanced energy expenditure. This was evidenced by

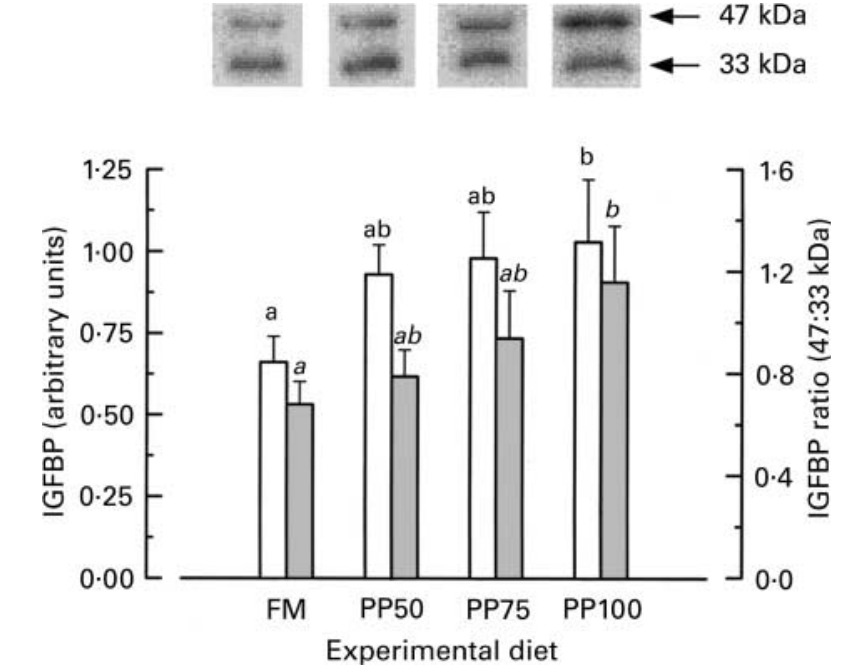

Fig. 5. A representative Western ligand blot of insulin-like growth factor-binding proteins (IGFBP) in fish fed the four experimental diets is shown at the top of the figure. The plot below indicates the integrated area (arbitrary units) for the two IGFBP bands $(\square)$ and the calculated ratio of $47 \mathrm{kDa}$ IGFBP to $33 \mathrm{kDa}$ IGFBP (ם). For details of the experimental diets, see Table 1 (p. 354). Values are means with their standard error shown by vertical bars for eight animals. ${ }^{a, b}$ Mean values with unlike superscript letters (roman and italic) were significantly different $(P<0.05)$.

the reduction of feed efficiency and the retention of digestible $\mathrm{N}$ and lipid nutrients. However, it remains to be established the extent to which this growth impairment is due to the presence of anti-nutritional factors and/or changes in the amino acid profile and other specific nutrients.

In the present study, we also found that plasma GH levels increased in fish fed high plant protein diets, but we did not detect changes in hepatic GH binding (a measure of GHR protein expression). Similarly, hepatic GHR transcripts remained unaltered, but in peri-visceral adipose tissue and in some extent in white muscle, GHR mRNA were up-regulated in a progressive manner with the $75 \%$ and $100 \%$ replacement of fishmeal. Since GH has a lipolytic effect not mediated by IGF in fish (Vega-Rubín de Celis et al. 2003), it can be argued that the upregulation of plasma GH levels and adipose tissue GHR mRNA represents an effective manner to mobilize and metabolize energy substrates from peripheral lipid depots. In mammals, it is now recognized that catabolic states characterized by the increase of plasma GH titres are usually accompanied by the increased expression of GHR in skeletal muscle (Combes et al. 1997), but this is the first report of the up-regulation of GHR in a peripheral GH target tissue of a lower vertebrate species. This can be of special relevance to modulate $\mathrm{GH}$ action in a fish species with a clear hyposomatotropism $(\mathrm{GH}<2 \mathrm{ng} / \mathrm{ml})$ compared with other salmonid and non-salmonid fish (Pérez-Sánchez \& Le Bail, 1999).

The precise mechanism involved in the plasma GH rise in the absence of liver GH desensitization (no changes in hepatic GHR and IGF transcripts) remains to be elucidated. However, there is now increasing evidence for a regulatory role of IGFBP in IGF function and activity, and it appears likely that the increase in plasma IGFBP activity reported herein represents an effective way to limit the amount of biologically active IGF (free IGF fraction) for GH feedback inhibition in fish fed diets with a high plant 
protein content. In fish, there is now evidence of at least three IGFBP, including a high-molecular-weight form (40-50 kDa) and two IGFBP in the $31-24 \mathrm{kDa}$ size range (Kelley et al. 1992; Niu \& Le Bail, 1993; Park et al. 2000; Cheng et al. 2002). As in mammals, the higher-molecular-weight IGFBP is the most abundant circulating IGF carrier under normal physiological conditions. In contrast, lower-molecular weight IGFBP are often at or below the limit of detection in fed fish, and upregulated several fold under catabolic conditions (Kelley et al. 2001, 2002; Peterson \& Small, 2004). Since the cloning and sequencing of gilthead sea bream IGFBP-2 (Funkenstein et al. 2002) and zebrafish IGFBP-1 and -2 (Duan et al., 1999; Maures $\&$ Duan, 2002), it becomes likely that the $\leq 31 \mathrm{kDa}$ IGFBP, originally identified by Western ligand blotting, might indeed be IGFBP-1 and -2. Additionally, doublets of higher-molecularweight proteins might represent different glycosylated forms of IGFBP-3.

Two glycosylation sites are always utilized in mammalian IGFBP-3, whereas the alternative glycosylation site incorporates $5 \mathrm{kDa}$ of carbohydrates, accounting for the characteristic doublet $(4-45 \mathrm{kDa})$ with a core protein size of $29 \mathrm{kDa}$ (Firth \& Baxter, 2002). Fish IGFBP-3 also exists as glycosylated protein (Shimizu et al. 2003), and a doublet of 45-34 kDa has been found in coho salmon serum (Shimizu et al. 1999). In trout, we have also detected an IGFBP doublet of higher molecular weight, increasing the total IGFBP activity and the $47: 33 \mathrm{kDa}$ IGFBP with plant protein supply. It is now accepted that proteolytic cleavage is the predominant mechanism to release IGF from IGFBP (Bunn \& Fowlkes, 2003). However, post-translational modifications such as glycosylation regulate the rate of IGFBP proteolysis, protecting them against the action of metalloproteases. In trout, the precise mechanism responsible for the increased 47:33 kDa IGFBP remains unknown, but this condition can protect IGFP-3 against degradation, avoiding the release of free IGF (biologically active form).

In summary, partial cloning and sequencing of a trout GHR was accomplished by RT-PCR, and a tissue-specific regulation of GHR mRNA was evidenced as a result of a different nutritional condition. In fish fed diets high in plant protein, the combined increase of plasma GH titres and GHR mRNA in adipose tissue would enhance the lipolytic action of GH. Further, we suggest that the decrease in growth rates with plant protein supply is primarily due to a lower availability of free plasma IGF rather than to liver GH desensitization or defect in IGF synthesis and release at the systemic and autocrine-paracrine level.

\section{Acknowledgements}

This research was funded by European Union (Q5RS-200-30 068, 'Perspectives of Plant Protein Use in Aquaculture', PEPPA) and Spanish (AGL2002-00 551) projects. S. V.-R. was the recipient of a research grant from the Spanish National Research Council (CSIC, I3P Program). The authors thank M. C. Fabregat for her valuable technical assistance in biochemical analyses.

\section{References}

Association of Official Analytical Chemists, (1990) Official Methods of Analysis,pp. 684. [K Heldrich, editor]. Arlington, VA: AOAC.

Behncken SN \& Waters MJ (1999) Molecular recognition events involved in the activation of the growth hormone receptor by growth hormone. $J$ Mol Recognit 12, 355-362.
Björnsson BT (1997) The biology of salmon growth hormone: from daylight to dominance. Fish Physiol Biochem 17, 9-24.

Björnsson BT, Johansson V, Benedet S, Einarsdottir IE, Hldahj J, Ágústsson T \& Jönsson E (2002) Growth hormone endocrinology of salmonids: regulatory mechanisms and mode of action. Fish Physiol Biochem 27, 227-242, Special Issue 'Fish Growth and Metabolism. Experimental, Nutritional and Hormonal Regulation' [EM Plisetskaya, editor] (published in 2004).

Bolin DW, King RP \& Klosterman EW (1952) A simplified method for the determination of chromic oxide $\left(\mathrm{Cr}_{2} \mathrm{O}_{3}\right)$ when used as an index substance. Science 116, 634-635.

Bunn RC \& Fowlkes JL (2003) Insulin-like growth factor binding protein proteolysis. Trends Endocrinol Metab 14, 176-181.

Calduch-Giner JA, Duval H, Chesnel F, Boeuf G, Pérez-Sánchez J \& Boujard D (2001) Fish growth hormone receptor: molecular characterization of two membrane-anchored forms. Endocrinology 142, 3269-3273.

Calduch-Giner JA, Mingarro M, Vega-Rubín de Celis S, Boujard D \& Pérez-Sánchez J (2003) Molecular cloning and characterization of gilthead sea bream (Sparus aurata) growth hormone receptor (GHR). Assessment of alternative splicing. Comp Biochem Physiol 136B 1-13.

Chen TT, Shamblott M, Lin CM, Tang Y-L, Chan K-M, Cheng CL, Yang B-Y \& Marsh A (1994) Structure and evolution of growth hormone and insulin like growth factor genes. In Perspectives in Comparative Endocrinology, pp. 352-364 [KG Davey, RE Peter and SS Tobe, editors]. Ottawa, Ont.: National Research Council of Canada.

Cheng R, Chang KM \& Wu JL (2002) Different temporal expressions of tilapia (Oreochromis mossambicus) insulin-like growth factor-I and IGF binding protein-3 after growth hormone induction. Mar Biotechnol 4, 218-225.

Chomczynski P \& Sacchi N (1987) Single-step method of RNA isolation by acid guanidinium thiocyanate-phenol-chloroform extraction. Anal Biochem 162, 156-159.

Choubert G, De la Noue J \& Luquet P (1982) Digestibility in fish: improved device for the automatic collection of feces. Aquaculture 29, 185-189.

Combes S, Louveau I \& Bonneau M (1997) Moderate feed restriction affects skeletal muscle and liver growth hormone receptors differently in pigs. $J$ Nutr 127, 1944-1949.

Company R, Astola A, Pendón C, Valdivia MM \& Pérez-Sánchez J (2001) Somatotropic regulation of fish growth and adiposity: growth hormone (GH) and somatolactin (SL) relationship. Comp Biochem Physiol 130B $435-445$.

Duan C, Ding J, Li Q, Tsai W \& Pozios K (1999) Insulin-like growth factor binding protein 2 is a growth inhibitory protein conserved in zebrafish. Proc Natl Acad Sci USA 96, 15274-15279.

Firth SM \& Baxter RC (2002) Cellular actions of the insulin-like growth factor binding proteins. Endocr Rev 23, 824-854.

Fukada H, Ozaki Y, Pierce AL, Adachi S, Yamauchi K, Hara A, Swanson P \& Dickhoff WW (2004) Salmon growth hormone receptor: molecular cloning, ligand specificity, and response to fasting. Gen Comp Endocrinol 139, 61-71.

Funkenstein B, Tsai W, Maures T \& Duan C (2002) Ontogeny, tissue distribution, and hormonal regulation of insulin-like growth factor binding protein-2 (IGFBP-2) in a marine fish, Sparus aurata. Gen Comp Endocrinol 128, 112-122.

Gómez-Requeni P, Mingarro M, Kirchner S, et al. (2003) Effects of dietary amino acid profile on growth performance, key metabolic enzymes and somatotropic axis responsiveness of gilthead sea bream (Sparus aurata). Aquaculture 220, 749-767.

Gómez-Requeni P, Mingarro M, Calduch-Giner JA, Médale F, Martin SAM, Houlihan DF, Kaushik S \& Pérez-Sánchez J (2004) Protein growth performance, amino acid utilisation and somatotropic axis responsiveness to fish meal replacement by plant protein sources in gilthead sea bream (Sparus aurata). Aquaculture 232, 493-510.

Johnsson JI, Jönsson E \& Björnsson BT (1996) Dominance, nutritional state, and growth hormone levels in rainbow trout (Oncorhynchus mykiss). Horm Behav 30, 13-21. 
Kelley KM, Siharath K \& Bern HA (1992) Identification of insulin-like growth factor-binding protein in the circulation of four teleost fish species. J Exp Zool 263, 220-224.

Kelley KM, Haigwood JT, Perez M \& Galima MM (2001) Serum insulinlike growth factor binding proteins (IGFBPs) as markers for anabolic/ catabolic condition in fishes. Comp Biochem Physiol 129B 229-236.

Kelley KM, Schmidt KE, Berg L, Sak K, Galima MM, Gillespie C, Balogh L, Hawayek A, Reyes JA \& Jamison M (2002) Comparative endocrinology of the insulin-like growth factor-binding protein. J Endocrinol 175, 3-18.

Kumar S, Tamura K, Jakobsen IB \& Nei M (2001) MEGA2: Molecular Evolutionary Genetics Analysis software. Bio informatics 17, 1244-1245.

Lee LT, Nong G, Chan YH, Tse DL \& Cheng CH (2001) Molecular cloning of a teleost growth hormone receptor and its functional interaction with human growth hormone. Gene 270, 121-129.

Livak KJ \& Schmittgen TD (2001) Analysis of real time gene expression data using real time quantitative PCR and the 2 (T) (Delta-Delta C) method. Methods 25, 402-408.

Maures TJ \& Duan C (2002) Structure, developmental expression, and physiological regulation of zebrafish IGF binding protein-1. Endocrinology 143, 2722-2731.

Maynard LA \& Loosli JK (1969) Animal Nutrition, 6th ed. pp. 613, New York: McGraw-Hill Book Co. Inc.

National Research Council (1993) Nutrient Requirements of Fish, pp. 124 Washington, DC: National Academy Press.

Niu D \& Le Bail P-Y (1993) Presence of insulin-like growth factor binding-protein (IGF-BP) in rainbow trout (Oncorhynchus mykiss) serum. Exp Zool 265, 627-636.

Park R, Sheperd BS, Nishioka RS, Grau EG \& Bern HA (2000) Effects of homologous pituitary hormone treatment on serum insulin-like growth factor-binding proteins (IGFBPs) in hypophysectomized tilapia, Oreochromis mossambicus, with special reference to a novel 20-kDa IGFBP. Gen Comp Endocrinol 117, 404-412.

Pérez-Sánchez J (2000) The involvement of growth hormone in growth regulation, energy homeostasis and immune function in the gilthead sea bream (Sparus aurata): a short review. Fish Physiol Biochem 22, 135-144.

Pérez-Sánchez J \& Le Bail P-Y (1999) Growth hormone axis as marker of nutritional status and growth performance in fish. Aquaculture 177, $117-128$.

Pérez-Sánchez J, Martí-Palanca H \& Kaushik S (1995) Ration size and protein intake affect circulating growth hormone concentration, hepatic growth hormone binding and plasma insulin-like growth factor-I immunoreactivity in a marine teleost, the gilthead sea bream (Sparus aurata). J Nutr 125, 546-552.

Pérez-Sánchez J, Calduch-Giner JA, Mingarro M, Vega-Rubín de Celis S, Gómez-Requeni P, Saera-Vila A, Astola A \& Valdivia MM (2002) Overview of fish growth hormone family. New insights in genomic organization and heterogeneity of growth hormone receptors. Fish Physiol Biochem 27, 243-258, Special Issue 'Fish Growth and Metabolism. Experimental, Nutritional and HormonalHormonal Regulation' [EM Plisetskaya, editor] (published in 2004).
Peterson BC \& Small BC (2004) Effects of fasting on circulating IGFbinding proteins, glucose, and cortisol in channel catfish (Ictalurus punctatus). Domest Anim Endocrinol 26, 231-240.

Pottinger TG, Rand-Weaver M \& Sumpter JP (2003) Overwinter fasting and re-feeding in rainbow trout: plasma growth hormone and cortisol levels in relation to energy mobilisation. Comp Biochem Physiol 136B 403-417.

Saera-Vila A, Calduch-Giner JA \& Pérez-Sánchez J (2005) Duplication of growth hormone receptor (GHR) in fish genome. Gene organization and transcriptional regulation of GHR type I and Type II in gilthead sea bream (Sparus aurata). Gen Comp Endocrinol 142, 193-203.

Shimizu M, Swanson P \& Dickhoff WW (1999) Free and protein-bound insulin-like growth factor-I (IGF-I) and IGF-binding proteins in plasma of coho salmon, Oncorhynchus kisutch. Gen Comp Endocrinol 115, 398-405.

Shimizu M, Swanson P, Hara A \& Dickhoff WW (2003) Purification of a $41 \mathrm{kDa}$ insulin-like growth factor binding protein from serum of Chinook salmon, Oncorhynchus tshawytscha. Gen Comp Endocrinol 132, $103-111$.

Small BC, Soares JH, Woods LC III \& Dahl GE (2002) Effect of fasting on pituitary growth hormone expression and circulating growth hormone levels in striped bass. North Am J Aquacult 64, 278-283.

Thompson JD, Higgins DG \& Gibson TJ (1994) CLUSTALW: improving the sensitivity of progressive multiple sequence alignment through sequence weighting, position-specific gap penalties and weight matrix choice. Nucleic Acids Res 22, 4673-4680.

Tse DLY, Tse MCL, Chan CB, Deng L, Zhang WM, Lin HR \& Cheng CHK (2003) Sea bream growth hormone receptor: molecular cloning and functional studies of the full length cDNA, and tissue expression of two alternatively spliced forms. Biochim Biophys Acta 1265, 64-76.

Tusnády GE \& Simon I (2001) The HMMTOP transmembrane topology prediction server. Bioinformatics 17, 849-850.

Varnavsky VS, Sakamoto T \& Hirano T (1995) Effects of premature seawater transfer and fasting on plasma growth hormone levels of yearling coho salmon (Oncorhynchus kisutch) parr. Aquaculture 135, 141-145.

Vega-Rubín de Celis S, Gómez P, Calduch-Giner JA, Médale F \& PérezSánchez J (2003) Expression and characterization of European sea bass (Dicentrarchus labrax) somatolactin: assessment of in vivo metabolic effects. Mar Biotechnol 5, 92-101.

Weber GM \& Grau EG (1999) Changes in serum concentrations and pituitary content of the two prolactins and growth hormone during the reproductive cycle in female tilapia, Oreochromis mossambicus, compared with changes during fasting. Comp Biochem Physiol 124C $323-335$.

Yao K, Niu P-D, Le Gac F \& Le Bail P-Y (1991) Presence of specific growth hormone binding sites in rainbow trout (Oncorhynchus mykiss) tissues: characterization of the hepatic receptor. Gen Comp Endocrinol 81, 72-82.

Zhu T, Goh ELK, Graichen R, Ling L \& Lobie PE (2001) Signal transduction via the growth hormone receptor. Cell Signal 13, 599-616. 